\title{
Reproductive phenology of three species of Gelidiales (Rhodophyta) in two macroalgal communities from Tenerife (Atlantic Ocean, Canary Islands, Spain)
}

\author{
Milena Polifrone ${ }^{1 *}$, María Candelaria Gil-Rodríguez ${ }^{2}$, Susana Domínguez Alvárez ${ }^{2}$, Mascha Stroobant ${ }^{1}$ \\ \& María Ascensión Viera-Rodríguez ${ }^{1}$ \\ ${ }^{1}$ Departamento de Biología, Universidad de Las Palmas de Gran Canaria, Campus Universitario de Tafira, E-35017 Las Palmas de Gran Canaria, Spain \\ milpol@inwind.it; maschastroobant@doctorandos.ulpgc.es; mviera@ulpgc.es \\ ${ }^{2}$ Departamento de Biología Vegetal (Botánica), Universidad de La Laguna, E-38071 La Laguna, Spain. mcgil@ull.es
}

\begin{abstract}
Polifrone, M., Gil-Rodríguez, M.C., Domínguez Álvarez, S., Stroobant, M. \& Viera-Rodríguez, M.A. 2012. Reproductive phenology of three species of Gelidiales (Rhodophyta) in two macroalgal communities from Tenerife (Atlantic Ocean, Canary Islands, Spain). Anales Jard. Bot. Madrid 69(2): 247-252.

The reproductive phenology of three species of Gelidiales, Gelidium canariense, Gelidium arbuscula and Pterocladiella capillacea, was analysed seasonally for a period of one year in two localities on the West coast of Tenerife (Atlantic Ocean, Canary Islands, Spain). Considerations are provided on sex ratio, maximum length and branch order of uprights and on the length of the thalli for each sexual and asexual phase of the Canary Islands populations. The three species were characterized by a high percentage of tetrasporophytes, while female and male gametophytes have been observed only in little proportion. Only G. canariense showed gametophytes in all seasons while the occurrence of gametophytes in G. arbuscula and Pterocladiella capillacea demonstrated a clear seasonality.
\end{abstract}

Keywords: sex ratio, thallus size, branching order, reproduction, Gelidiales.

\section{INTRODUCTION}

Gelidialean algae play a key role in highly exposed rocky intertidal ecosystems where they can form communities that look like miniature forests and create a favourable environment for the survival of associated species of flora and fauna (Hay, 1981). In Canary Islands, these communities mainly consist of three species: Gelidium arbuscula Bory de SaintVincent ex Børgesen, Gelidium canariense (Grunow) SeoaneCamba ex Haroun, Gil-Rodríguez, Díaz de Castro et Prud'homme van Reine and Pterocladiella capillacea (S.G. Gmelin) Santelices \& Hommersand.

Gelidium arbuscula and G. canariense are two endemic and protected species of Canary Islands and grow along the northern coasts of the western islands, El Hierro, La Palma, La Gomera, Tenerife and Gran Canaria (Haroun \& al., 2002). Pterocladiella capillacea is a widespread species, frequent in temperate and tropical seas, and is common throughout the islands of the Canary Archipelago, with a wider distribution along its shores than the two former species of Gelidium (Haroun \& al., 2002). These perennial species appear as a mixed belt or as three well-marked successive monospecific belts that represents the most important coastal communities in high exposed ecosystems of the islands (Mercado \& al.,

\section{Resumen}

Polifrone, M., Gil-Rodríguez, M.C., Domínguez Álvarez, S., Stroobant, M. \& Viera-Rodríguez, M.A. 2012. Fenología reproductiva de tres especies de Gelidiales (Rhodophyta) en dos comunidades de macroalgas de Tenerife (Océano Atlántico, Islas Canarias, España). Anales Jard. Bot. Madrid 69(2): 247-252 (en inglés).

La fenología reproductiva de tres especies de Gelidiales, Gelidium canariense, Gelidium arbuscula y Pterocladiella capillacea, ha sido analizada estacionalmente por un periodo de un año en dos localidades de la costa este de Tenerife (Oceano Atlántico, Islas Canarias, España). Se realizan consideraciones sobre sex ratio, longitud máxima y orden de ramificación de los ramets y se aporta información sobre la longitud del talo por cada fase sexual y asexual de las poblaciones canarias. Las tres especies se caracterizan por presentar un elevado porcentaje de tetrasporofitos, mientras que los gametofitos masculinos y femeninos han sido observados en proporciones reducidas. Sólo G. canariense presenta gametofitos en todas las estaciones, mientras que en G. arbuscula y Pterocladiella capillacea demostraban una clara estacionalidad.

Palabras claves: sex ratio, longitud del talo, orden de ramificación, reproducción, Gelidiales.

2001). When they form separate belts, about $3-5 \mathrm{~m}$ wide in total (Haroun \& al., 2003), their zonation is well defined with a vertical distribution characterized by $P$. capillacea, G. arbuscula and G. canariense from the lower intertidal to the upper subtidal, as described by Gil-Rodríguez \& Wildpret (1980), Pinedo \& Afonso-Carrillo (1994) and Domínguez-Álvarez \& al. (2011).

The potential utilization of these species as source of agar induced the collection of Gelidium and Pterocladiella at Puerto de la Cruz (Tenerife) from 1951 to 1966. The exploitation of agarophytes in Canary Islands did not persist due to different commercial, social and scientific events such as the spatial limitation of the algae, the increase of the touristic area and the better paid work in this field (Afonso-Carrillo, 2003). Although the industrial activity could not get ahead, the communities of Gelidiales maintained their ecological value because they represent the most extended algal communities in the northern coast of the main islands; they sustain a rich ecosystem in highly exposed environments and because of their endemic character. Both G. canariense and G. arbuscula are currently included in the Catalogue of Endangered Species of the Canary Islands (Law 4/2010, BOC $n^{\circ} 112$, $9^{\text {th }}$ June 2010). Nevertheless, in Tenerife the communities of Gelidiales are undergoing a severe process of regression; in fact, 
we observed a significant reduction in these communities 35 years after the observations of Lawson \& Norton (1971).

All three species have a clump organization of one to several genetically different individuals (genets) formed by one or more upright axes or ramets that develop from a basal system of prostrate axes attached to the substratum by rhizoids. The clump is a modular construction that can be the result of sexual reproduction and originate from the germination of a single spore or from different spores germinated close each other producing different genets growing in the same modular organization. Its structure is complicated by the vegetative growth of new uprights from the prostrate axes (Santos, 1995; Santelices, 1999; Scrosati \& Serviére-Zaragoza, 2000; Santelices, 2004; Scrosati, 2001, 2005).

The genera Gelidium and Pterocladiella have a Polysiphonia-type life history (Kylin, 1956) which is accompanied by the presence of vegetative propagation (Dixon, 1958, 1963; Felicini \& Perrone, 1994; Perrone \& al., 2006) where new fronds can arise from the basal attachment system (an entangled base of stolons attached to the substratum by rhizoidal organs). Although the haploid dioecious gametophytes and the diploid tetrasporophytes are reported as isomorphic in Gelidiales, Santos \& Duarte (1996) showed that ramets of Gelidium sesquipedale (Clemente) Thuret from different life cycle phases were morphologically different and thus that these life cycles are not really isomorphic. In fact, cystocarpic fronds were shorter and have more branches than tetrasporophytes. Little is known about the life history of natural populations of Gelidiales in Canary Islands and there are no exhaustive studies to date, despite some attempts have been done by Sosa \& García Reina (1992) and Lindgren \& al. (1998). Understanding the biological pattern of the species considered in this study is essential for the management of their natural population and of such important coastal ecosystems in the Canary Islands. The reproductive phenology of endangered species with an important ecological role is one of the aspects to take into account in the management of natural populations in order to know the influence of possible negative impact on populations. The knowledge of the periods of maximum growth and reproduction of the thalli enable to develop better strategies of monitoring of these populations. Therefore the aim of the present study was to investigate the reproductive seasonal pattern, the relative proportion of asexual and sexual phases and the sex-ratio of these three species at two localities in Tenerife. Another goal was to determine if morphological differences in the maximum thallus size and branch order could be determinant in the distinction of fertile thalli in contrast with the current paradigm of isomorphism of Gelidiales.

\section{MATERIAL AND METHODS}

The three species were collected from natural populations in two study sites in Tenerife: Garachico (UTM3700288/ 3590165) and Puerto de la Cruz (UTM 3675447/3588716) (Fig. 1).

Both sites have similar pattern of marine vegetation, characterized by three belts of Gelidiales with P. capillacea above, G. arbuscula in the middle and G. canariense below. They are subjected to high hydrodynamic regime and to semidiurnal

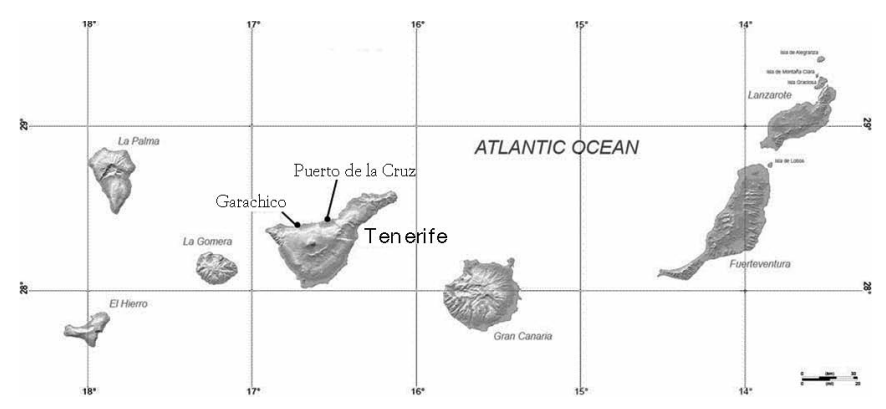

Fig. 1. Map of Canary Islands (Atlantic Ocean) indicating the study sites of Garachico and Puerto de la Cruz on the north coast of Tenerife.

tides (Domínguez-Álvarez \& al., 2011). The photoperiod ranged from $13 \mathrm{~L}: 9 \mathrm{D}$ in June and July to $9 \mathrm{~L}: 13 \mathrm{D}$ in December; and the global solar radiation ranged from $7.81 \mathrm{KWh}$ $\mathrm{m}^{-2} \mathrm{day}^{-1}$ in May to $3.52 \mathrm{KWh} \mathrm{m}^{-2} \mathrm{day}^{-1}$ in December. The highest temperature was of $24.1^{\circ} \mathrm{C}$ in September and the lowest was of $18.4^{\circ} \mathrm{C}$ in February.

We made a random collection of 20 clumps for species in each locality in the four seasons during the year 1999. Sampling was done seasonally during the lowest tides and the samples, individually separated in plastic bags, were transported immediately to the laboratory of the Botany Department of the University of La Laguna (ULL) and preserved in labelled jars containing a $4 \%$ formalin-seawater solution.

We studied the phenological pattern estimating both the percentage of reproductive clumps and the percentage of reproductive ramets. The incidence of reproductive phases and their relative frequency in the natural populations was also determined: for each clump we selected five ramets among the most developed upright axes to obtain a total of $100 \mathrm{ram}-$ ets for season, locality and species, which were separated according to their sexual phase under a stereoscopic microscope. The classification of the ramets was done as follows: tetrasporophytes bearing tetrasporangia, gametophytes bearing spermatangia and female gametophytes bearing cistocarps, including senescent and immature reproductive structures observed under an optical microscope; all ramets without any kind of reproductive structure were considered as sterile. A clump was considered reproductive when it was possible to identify at least one reproductive ramet within its structure. All the examined specimens were deposited in the herbarium TFC of the University of La Laguna (Canary Islands). We also calculated the sex ratio of all species taking into account the proportion of fertile ramets or clumps $v$ s. unfertile ramets or clumps. Length (measured from the prostrate system to the apex) and branching order (without considering the last ramula bearing the reproductive structures) of each selected ramet have been considered to assess the maximum size of the three species in natural populations and its relation to the fertile status. The frequencies of male and female gametophytes, tetrasporophytes and sterile ramets have been sorted according to the following size classes ( $\mathrm{Zi}$ dane \& al., 2006): less than $4 \mathrm{~cm}$, from $4.1 \mathrm{~cm}$ to $6 \mathrm{~cm}$; from $6.1 \mathrm{~cm}$ to $8 \mathrm{~cm}$; from $8.1 \mathrm{~cm}$ to $10 \mathrm{~cm}$; from $10.1 \mathrm{~cm}$ to $12 \mathrm{~cm}$; from $12.1 \mathrm{~cm}$ to $14 \mathrm{~cm}$; more than $14 \mathrm{~cm}$. Analysis of data was performed using the statistical package PASW Statistic 
18.0.3, separating the frequencies of reproductive and sterile phases into size classes using contingency tables and evaluating its significance by the Pearson chi square test.

\section{RESULTS}

The reproductive pattern of $G$. canariense and P. capillacea was characterized by the presence of a high percentage of tetrasporophytic clumps which increased from winter to autumn (Fig. 2), while G. arbuscula had the higher amount of tetrasporophytic clumps in the summer-autumn period, decreasing in spring and summer (Fig. 2). While in G. canariense we could observe female clumps throughout the year with a higher percentage in autumn (when the temperature reaches its maximum values, and solar radiation is decreasing), we found female clumps of G. arbuscula and P. capillacea only in winter (at low temperature and solar radiation) and summer (at low temperature and high solar radiation) respectively. Male gametophytes were rarely found in G. canariense, being present in winter and spring at low temperature and solar radiation; in P. capillacea they were found only in autumn and in a very low percentage (at high temperature and decreasing solar radiation). No male clumps of G. arbuscula were found during the four seasons of the study. Percentage of sterile clumps decreased from winter to summer in G. canariense, while in $G$. arbuscula they have been found only in spring and summer, with a higher percentage in the latter season. In $P$. capillacea, sterile clumps have been found only in winter and spring, with almost the same percentage.

Generally we found that tetrasporophytic clumps had fewer sterile ramets while male and female gametophytic clumps were characterized by a lower percentage of reproductive ramets resulting in a slightly different proportion of phases in the phenological study (Fig. 2).

In fact, the reproductive ratio observed for clumps of $G$. canariense of Tenerife was of 12:3:1 (t:f:m), 33:1:0 (t:f:m) for G. arbuscula and 133:1:1 (t:f:m) for P. capillacea. When we considered the ramets, the reproductive ratio was of 19:4:1 (t:f:m) for G. canariense, 109:1:0 (t:f:m) for G. arbuscula and 165:1:1 (t:f:m) for P. capillacea.

Gelidium canariense had a maximum length of $23.8 \mathrm{~cm}$ and branching order up to 7; $G$. arbuscula had a maximum length of $12.9 \mathrm{~cm}$ and branching order up to 8; P. capillacea had a maximum length of $19 \mathrm{~cm}$ and branching order up to 7 . The size class most represented in G. arbuscula was between 4.1 and $6 \mathrm{~cm}$ for all fertile and sterile phases (Fig 3a). Pearson chi square test showed significant differences between sizes of the tetrasporophytes $(\mathrm{P}<0.001)$ due to a higher frequency of tetrasporophytes in the class from 4.1 to $6 \mathrm{~cm}$. Differences between the size classes of sterile ramets were not significant. In G. arbuscula, female gametophytes were present in only winter, while tetrasporophytes were more frequent in autumn and longer in winter; sterile ramets were more frequent in spring-summer.

In G. canariense, all sterile and fertile phases showed significant differences in the size classes according to the Pearson chi square test $(\mathrm{P}<0.001)$. The size classes most frequently represented were from $4.1 \mathrm{~cm}$ to more than $14 \mathrm{~cm}$ (Fig 3b) with reproductive ramets mainly distributed in size classes a

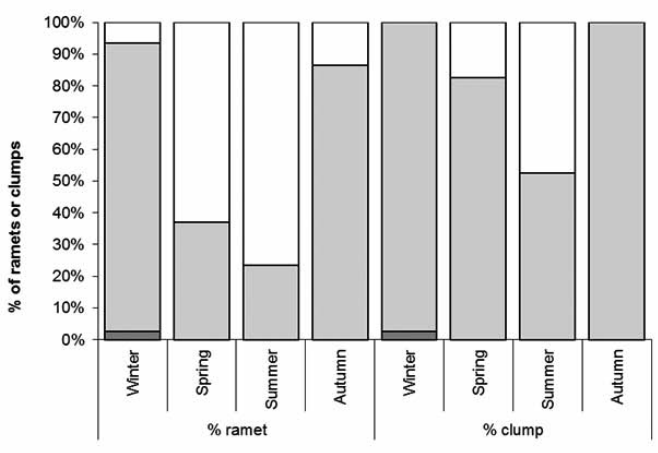

b

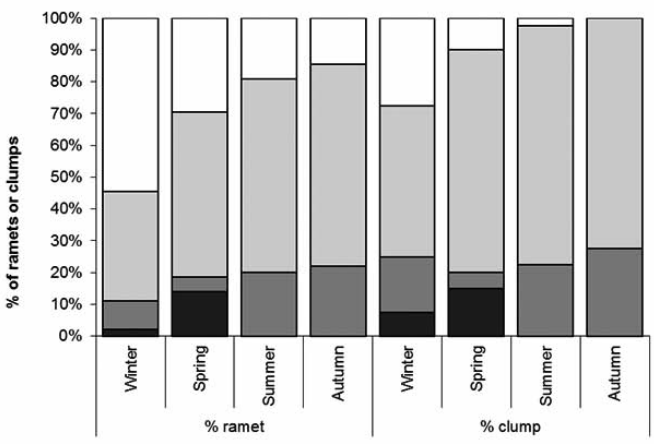

C

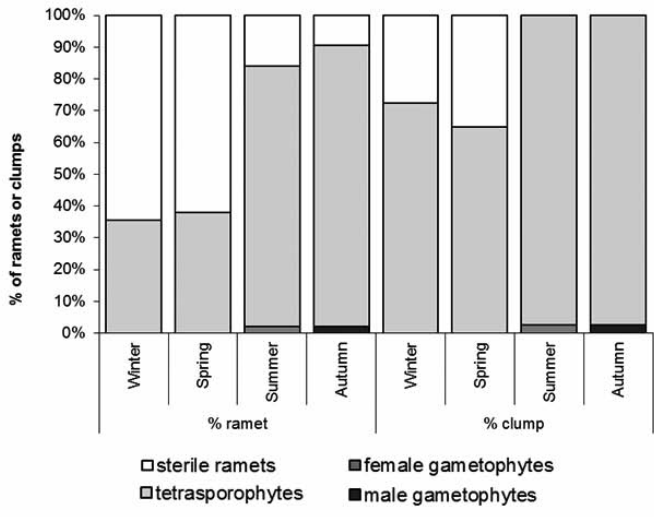

Fig. 2. Percentage of ramets or clumps of Gelidium arbuscula (a), G. canariense (b) and Pterocladiella capillacea (c) according to their fertile status in the four seasons.

greater than $6 \mathrm{~cm}$ and sterile ramets in size classes mostly below $10 \mathrm{~cm}$. This species showed more developed male gametophytes in spring, while female gametophytes were longer in autumn at nearly all the size class of higher frequency. Moreover, tetrasporophyte length had a fairly constant value during the four seasons although the ramets were longer in spring and summer (size class over $14 \mathrm{~cm}$ ) than in autumn (size class from 8.1 to $10 \mathrm{~cm}$ ). Sterile ramets were mainly frequent during winter and gradually reduced in the rest of year.

Pterocladiella capillacea was mostly distributed in the size classes from $4.1 \mathrm{~cm}$ to $10 \mathrm{~cm}$ : male and female gametophytes and sterile ramets were reduced in length respect to the tetrasporophytes. (Fig. 3c). All phases showed significant differences between size classes due to the presence of peaks of frequencies in the size class of 6.1 to $8 \mathrm{~cm}$. Sterile ramets were more frequent and longer in winter and spring, while tetrasporophytes were more frequent in autumn and longer in 
a

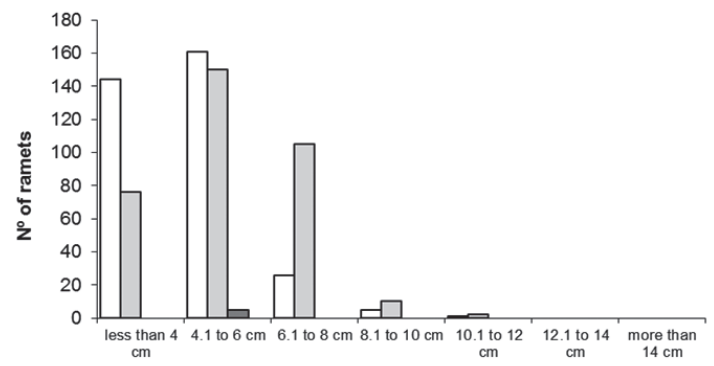

b

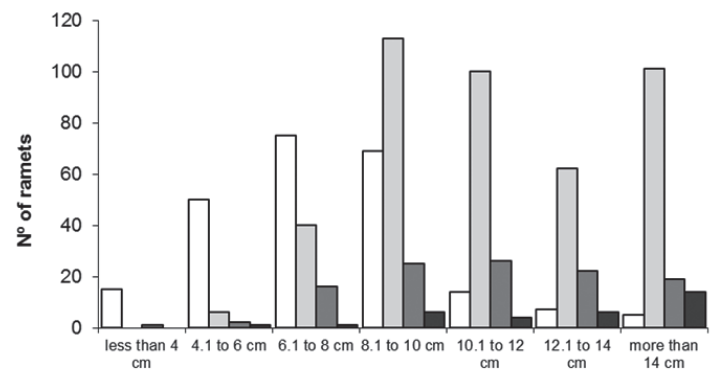

C

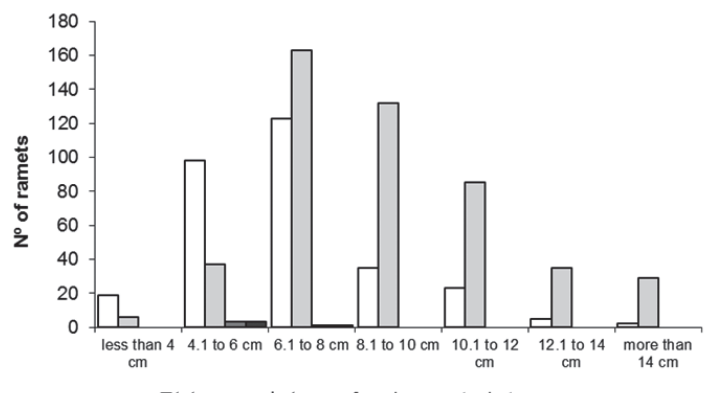

$\square$ aterile ramets $\square$ tetrasporophytes $\square$ female gametophytes $\square$ male gametophytes

Fig. 3. Distribution of size classes of Gelidium arbuscula (a), G. canariense (b) and Pterocladiella capillacea (c) according to their fertile status.

summer-autumn. Male gametophytes were present in autumn at the size classes from 6 to $8 \mathrm{~cm}$, while female gametophytes were present in summer with a length between 6.1 and $8 \mathrm{~cm}$.

The branching order (Fig. 4) was similar for all reproductive phases in G. canariense, while sterile thalli were less branched. Gelidium arbuscula was highly branched in all reproductive and sterile ramets throughout the seasons except winter, when the branching order was lower. Pterocladiella capillacea showed the lowest branching order in female ramets and the highest in male ramets; tetrasporophytes had a constant branching order troughout the year with a reduction in winter, while sterile ramets were less branched in all seasons except spring.

When we considered the relation between the maximum length of ramets and their branch order (Fig. 4) we could observe a clear difference in the size of tetrasporophytes in comparison to other fertile or sterile ramets only in G. arbuscula. It was difficult to differentiate fertile phases on the basis of these morphological characters in the other two species. However, in P. capillacea male gametophytes in their period of maturity (autumn) could be differentiated for their higher branch order. In all species the sterile thalli could be identified as the smallest and less branched ramets.

\section{DISCUSSION}

Tetrasporophytes were most abundant and frequent throughout the year in the three studied species of Tenerife. Only G. canariense had gametophytes in all seasons, though in small percentage. The ratio between gametophytes and tetrasporophytes of $G$. canariense (t:f:m $=12: 3: 1$ ) differed from that described by Darias-Rodríguez \& Afonso-Carrillo (1986) in Tenerife (t:f:m = 3:1:1) and by other authors (Sosa \& García-Reina, 1993; Sosa \& al., 1993; Lindgren \& al., 1998 ) in Gran Canaria ( $t: f=5: 1$ ). There are no previous data on the sex ratio or haploid:diploid ratio of G. arbuscula. In $P$. capillacea, our results showed a higher proportion of tetrasporophytes（t:f:m =133:1:1） than that one observed by Oliveira \& Berchez (1993) in Brazil where these authors found a frequency of tetrasporophytes of $50 \%$ against $1-2 \%$ of male gametophytes and 3-4\% of female gametophytes. These results evidenced that seasonality in the formation of tetraspores proposed by Santelices (1988) for these genera did not occur in Canary populations, in accordance with the observations of Melo \& Neushul (1993) in populations of Gelidium robustum (N.L.Gardner) Hollenberg \& I.A. Abbott from California.

A different degree of deviation from the balanced haploid:diploid ratio is often observed and tetrasporophytes have been described as several orders of magnitude more frequent than gametophytes, the sexual phases being completely absent in some cases (Akatsuka, 1986; Santelices, 1988; Santos \& Duarte, 1996; Bottalico \& al., 2008). The unequal distribution of tetrasporophytes and gametophytes was explained by physiological differences between the two phases (Santelices, 1990), although Sosa \& al. (1993) indicated that physiological characteristics were not responsible for the scarcity of gametophytes in the populations of $G$. canariense of Gran Canaria (Canary Islands). Carmona \& Santos (2006) did not observe any ecophysiological advantage of tetrasporophytes over gametophytes in G. sesquipedale a part of a higher vegetative recruitment and spore production. Isozyme studies performed on G. arbuscula by Sosa \& al. (1998) revealed different allele frequencies in gamethophytes and tetrasporophytes which could influence the survival of one or the other phase. However, Vieira \& Santos (2010) observed that very small differences in the vital rates between the two phases can have strong effects on the haploid:diploid ratio. In fact, they found that the fecundity of tetrasporophytes was considered 16times higher than those of gametophytes in G. sesquipedale.

Even though we did not consider all the ramets within each clump and further studies on the modular structure of these three species of the Canary Islands are needed, we did not found gametophytic and tetrasporophytic phases mixed in the same clump. As pointed out by Ardito \& Gómez (2005), the count of sterile thalli is essential when there is a deviation from the expected ratio among the different phases of the life cycle, because most thalli regarded as sterile could be immature or senescent gametophytes or tetrasporophytes and should contribute to the sex ratio. In fact, when comparing the ratio based on clumps or on ramets, little differences were observed in G. canariense and P. capillacea and a high variation was recorded in G. arbuscula. In the latter species this si- 


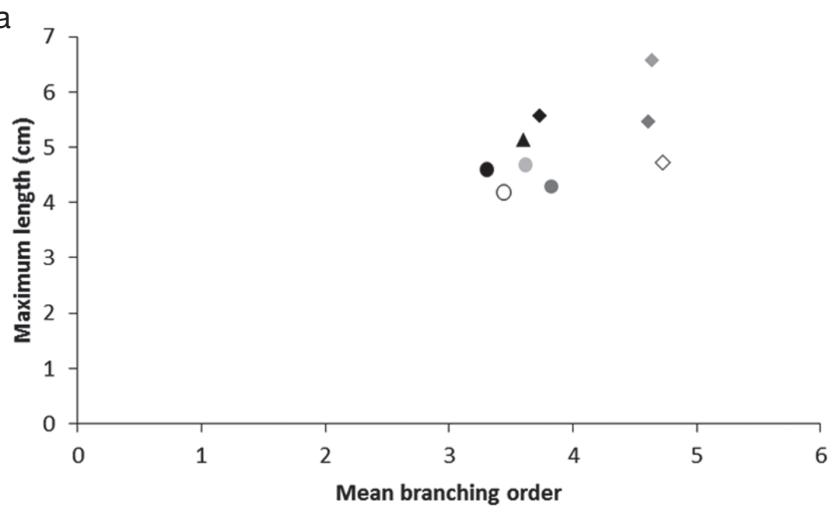

b

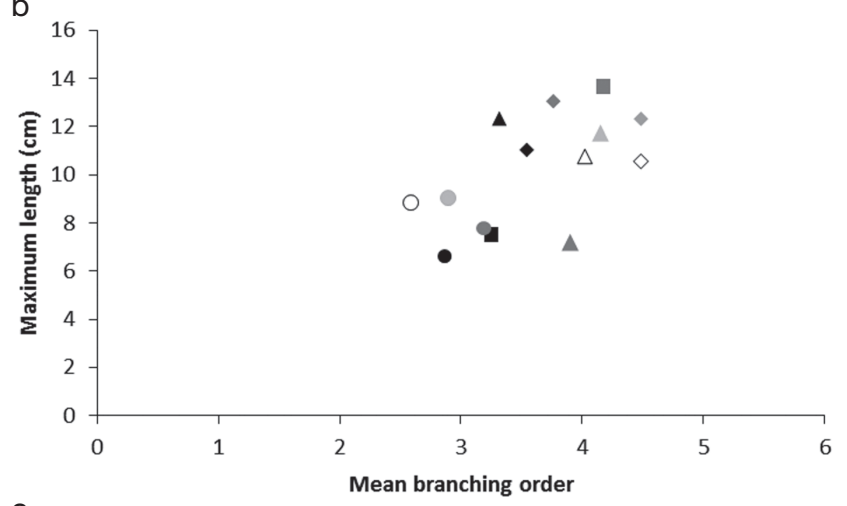

C

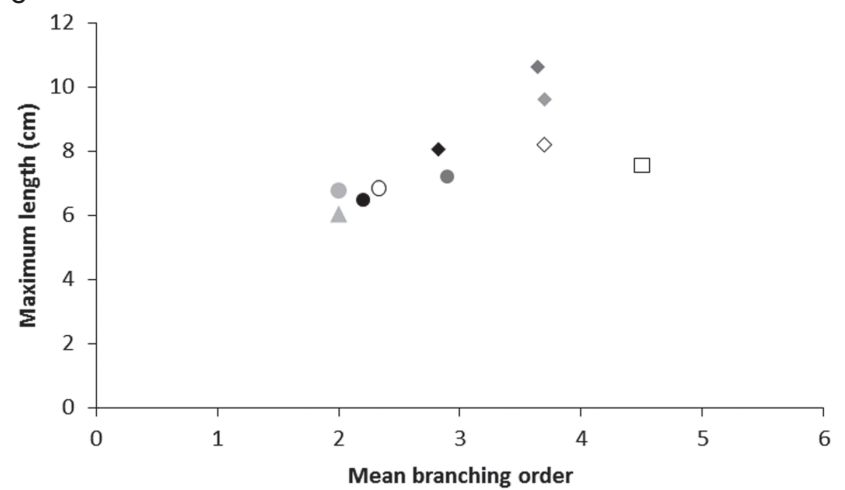

Fig. 4. Maximum length and branching order of ramets of Gelidium arbuscula (a), G. canariense (b) and Pterocladiella capillacea (c) according to their fertile status in the four seasons. - Sterile, $\boldsymbol{\Delta}$ Female gametophytes, Male gametophytes, Tetrasporophytes. Colours: black, winter; dark grey, spring; light gray, summer; white, autumn.

tuation was due to the presence of a higher percentage of sterile ramets in the clumps sorted as gametophytic.

Although the three species belong to the same order, have a similar modular organization and are subjected to the same environmental conditions, it was not possible to observe a common pattern in the frequency of male and female gametophytes during the year of study. Differences were also observed when they were compared with populations of the same species or genus from other localities (Oliveira \& Berchez, 1993; Serviere-Zaragoza \& Scrosati, 2002). In accordance with the observations of Oliveira \& Sazima (1973) who found male gametophytes from December to April and female only in April in populations of P. capillacea of Brazil, we observed the presence of female and male gametophytes of this species only during summer (at a temperature of 21-22 ${ }^{\circ} \mathrm{C}$ ) and autumn (temperature of $23-24{ }^{\circ} \mathrm{C}$ ) respectively. The differences observed in the occurrence of gametophytes suggested that other aspects rather than environmental factors and latitude could influence their development and survival in natural populations (Carmona \& Santos, 2006).

Frequencies and abundances of male and female gametophytes are very low in the Gelidiales (Montalva \& Santelices, 1981; Akatsuka, 1986; Ardito \& Gómez, 2005), especially because male gametophytes are often difficult to discriminate from sterile thalli and female gametophytes are difficult to be recognized in the field before fertilization and are usually taken into account only after the development of the cystocarp. The studies that report the frequency of male and female thalli in the Gelidiales populations are very scarce and they report a sex ratio of 1:1 (Guzmán del Próo \& al., 1972; Melo and Neushul, 1993; Ardito \& Gómez, 2005; Carmona \& Santos, 2006) as we found here in populations of $P$. capillacea. In our study the ratio of male $v$ s. female gametophytes was different for the other two species, since male thalli were not found or not recognized in G. arbuscula and were very poorly represented in G. canariense (1:4, m:f).

The thallus size observed was lower than that described for these species in Canary Islands. In fact, Seoane-Camba (1979) reported a mean length of $G$. canariense (as Gelidium cartilagineum var. canariensis Grunow) of $25 \mathrm{~cm}$ (maximum of 30 $\mathrm{cm}$ ), Børgesen (1927) reported a maximum length of G. arbuscula (as G. arbuscula Bory) of $15 \mathrm{~cm}$ and Stroobant (2004) reported a mean length of $P$. capillacea at Puerto de la Cruz (Tenerife, Canary Islands) of $9.74 \mathrm{~cm}$. This is the first study reporting the relationship between ramet size and fertile status of these species from Canary Islands. Besides the differences in thallus size typical of each species, we have observed that ramet size (maximum length and branching order) were generally lower in sterile thalli than in reproductive ones suggesting that they represent undifferentiated ramets which will develop into fertile ramets. The presence of small uprights in late autumn was interpreted as the evidence that the production of new uprights from stolons occurred in late autumn-winter in P. capillacea (Bottalico \& al., 2008). In G. sesquipedale the presence of smaller size classes in autumn was related to the presence of young thalli while the presence of higher size classes in winter was related to mature and reproductive thalli (Zidane \& al., 2006). These observations suited for the populations of Tenerife of $P$. capillacea and G. canariense, while it did not match the pattern observed in G. arbuscula, where the formation of new uprights seems to be continuous during the year.

Slight morphological differences between tetrasporophytes and gametophytes were observed only in G. arbuscula and $P$. capillacea. However, tetrasporophytes differed only in the period of maximum development, while in winter they showed sizes comparable to the gametophytes so that these characters are difficult to use to discern haploid and diploid phases. In P. capillacea gametophytes were generally more branched than tetrasporophytes and sterile ramets, maybe reflecting the need to increase the reproductive effort through the formation of a higher number of branches bearing reproductive structures to supply the reduced number of fertile ramets developed. 


\section{ACKNOWLEDGEMENTS}

We acknowledge the help of Mr. A. Redondo Arolas. (Instituto Universitario de Sistemas Inteligentes y Aplicaciones Numéricas en Ingeniería. ULPGC) and Ms. M. Locritani (Istituto Nazionale di Geofisica e Vulcanologia - INGV).

\section{REFERENCES}

Afonso-Carrillo, J. 2003. Aprovechamiento industrial de algas marinas canarias para la extracción de agar. Puerto de la Cruz (1951-1966). El Pajar. Cuaderno de Etnografía Canaria 15: 173-184.

Akatsuka, I. 1986. Japanese Gelidiales (Rhodophyta), specially Gelidium. Oceanography and Marine Biology: Annual Review 24: 171-263.

Ardito, S. \& Gómez, S. 2005. Patrón fenológico de una población de Gelidium serrulatum J. Agardh (Rhodophyta, Gelidiales) en el Estado Vargas, Venezuela. Acta Botánica Venezuelica 28: 101-112.

Børgesen, F. 1927. Marine algae from the Canary Islands especially from Teneriffe and Gran Canaria. III. Rhodophyceae. Part I. Bangiales and Nemalionales. Kongelige Danske Videnskabernes Selskab, Biologiske Meddelelser 6: 80-93.

Bottalico, A., Delle Foglie, C.I. \& Fanelli, M. 2008. Growth and reproductive phenology of Pterocladiella capillacea (Rhodophyta: Gelidiales) from the southern Adriatic Sea. Botanica Marina 51: 124-131.

Carmona, R., \& Santos, R. 2006. Is there an ecophysiological explanation for the gametophyte-tetrasporophyte ratio in Gelidium sesquipedale (Rhodophyta)? Journal of Phycology 42: 259-269.

Darias-Rodríguez, R.M. \& Afonso-Carrillo, J. 1986. Reproducción y fenología de Gelidium versicolor (S.G. Gmelin) Lamouroux var. canariensis Grunow (Rhodophyta) en el Puerto de la Cruz (Tenerife). Abstracts of the V Simposio Ibérico de Benthos Marino.

Dixon, P.S. 1958. The structure and development of the thallus in the British species of Gelidium and Pterocladia. Annals of Botany, N.S. 22: 353-368.

Dixon, P.S. 1963. Variation and speciation in marine Rhodophyta. In: Speciation in the sea. The Systematics Association Pubblication 5: 51-62.

Domínguez-Álvarez, S., Rico, J.M. \& Gil-Rodríguez, M.C. 2011. Photosynthetic response and zonation of three species of Gelidiales from Tenerife, Canary Islands. Anales del Jardín Botánico de Madrid 68(1): 117-124.

Felicini, G.P. \& C. Perrone. 1994. Pterocladia. In: Akatsuka, I. (ed.), Biology of economic algae. SPB Acad. Publ. bv., The Hague. pp. 283-344.

Gil-Rodríguez, M.C. \& Wildpret, W. 1980. Contribución al estudio de la vegetación ficológica marina del litoral canario. Aula de Cultura. Excmo. Cabildo Insular de Tenerife.

Guzmán Del Próo, S.A., De La Campa-De Guzmán, S. \& Pineda-Barrera, J. 1972. Shedding rhythm and germination of spores in Gelidium robustum. Proceedings of the International Seaweed Symposium 7: 221-228.

Haroun, R.J., Gil-Rodríguez, M.C., Díaz de Castro, J. \& Prud'homme van Reine, W.F. 2002. A checklist of the marine plants from the Canary Islands (central eastern Atlantic Ocean). Botanica Marina 45: 139-169.

Haroun, R.J., Gil-Rodríguez, M.C. \& Wildpret de la Torre, W. 2003. Plantas Marinas de las Islas Canarias. Canseco Editores. Talavera de la Reina. 319 pp.

Hay, M.E. 1981. The functional morphology of turf-forming seaweeds: persistence in stressful marine habitats. Ecology 62: 739-750.

Kylin, H. 1956. Die Gattungen der Rhodophyceen. Gleerups, Lund, Sweden. $\mathrm{xv}+673,458$ figs.

Lawson, G.W. \& Norton, T.A. 1971. Some observations on the littoral and sublittoral zonation of Tenerife (Canary Isles). Botanica Marina 14: 116120.

Lindgren, A., Bouza, N., Aberg, P. \& Sosa, P. 1998. Spatial and temporal variation in distribution of Gelidium canariensis (Rhodophyta) from natural populations of the Canary Islands. Journal of Applied Phycology 10: 273-278.

Melo, R.A. \& Neushul, M. 1993. Life history and reproductive potential of the agarophyte Gelidium robustum in California. Hydrobiologia 260/261: 223-229.

Mercado, J.M., Niell, F.X. \& Gil-Rodríguez, M.C. 2001. Photosynthesis maybe limited by light, not inorganic carbon availability, in three intertidal Gelidiales species. New Phytologist 149: 431-439.

Montalva, S. \& Santelices, B. 1981. Interspecific interference among species of Gelidium from Central Chile. Journal of Experimental Marine Biology and Ecology 53: 77-88.
Oliveira, E.C. \& Sazima, I.P. 1973. Estudos sobre a biología de algas agarofitas I.- Recolonizaçao, brotamiento e fenología em populaçoes de Pterocladia capillacea (Rhodophyta, Gelidiaceae). Boletín Zoología y Biología Marina N.S. 30: 677-690.

Oliveira, E.C. \& Berchez, F.A.S. 1993. Resource biology of Pterocladia capil lacea (Gelidiales, Rhodophyta) populations in Brazil. Hydrobiologia 260/261, 255-261.

Perrone, C., Felicini, G.P. \& Bottalico, A. 2006. The prostrate system of the Gelidiales: diagnostic and taxonomic importance. Botanica Marina 49: 23-33.

Pinedo, S. \& Afonso-Carrillo, S. 1994. Distribución y zonación de las algas marinas bentónicas en el Puerto de la Cruz, Tenerife. Vieraea 23: 109-123.

Santelices, B. 1988. Synopsis of biological data on the seaweed genera Gelidium and Pterocladia (Rhodophyta). FAO Fisheries Synopsis 145: 1-55.

Santelices, B. 1990. Patterns of reproduction dispersal and recruitment in seaweeds. Oceanography and Marine Biology Annual Review 28: 177-276.

Santelices, B. 1999. How many kinds of individual are there? Tree 4: 152-155.

Santelices, B. 2004. A comparison of ecological responses among aclonal (unitary), clonal and coalescing macroalgae. Journal of Experimental Marine Biology and Ecology 300: 31-64.

Santos, R. 1995. Size structure and inequality in a commercial stand of the seaweed Gelidium sesquipedale. Marine Ecology Progress Series 119: 253. 263.

Santos, R. \& Duarte, P. 1996. Fecundity, spore recruitment and size in Gelidium sesquipedale (Gelidiales: Rhodophyta). Hydrobiologia 326/327: 223. 228.

Scrosati, R. 2001. Demography of genets of clonal red seaweeds: current limitations and proposed solutions using markers from experimental populations. Hidrobiológica 11(2): 149-155.

Scrosati, R. 2005. Review of studies on biomass-density relationships (including self-thinning lines) in seaweeds: main contributions and persisting misconceptions. Phycological Research 53: 224-233.

Scrosati, R. \& Servière-Zaragoza, E. 2000. Ramet dynamics for the clonal seaweed Pterocladiella capillacea (Rhodophyta): a comparison with Chondrus crispus and with Mazzaella cornucopiae (Gigartinales). Journal of Phycology 36: 1061-1068.

Servière-Zaragoza, E. \& Scrosati, R. 2002. Reproductive Phenology of Pterocladiella capillacea (Rhodophyta: Gelidiales) from Southern Baja California, Mexico. Pacific Science 56: 285-290.

Seoane-Camba, J. 1979. Sobre algunas gelidiáceas nuevas o poco conocidas de las costas españolas. Acta Botánica Malacitana 5: 99-112.

Sosa, P.A. \& García-Reina, G. 1992. Genetic variability and differentiation of sporophyte and gametophytes in populations of Gelidium arbuscula (Gelidiaceae: Rhodophyta) determined by isozymes electrophoresis. Marine Biology 113: 679-688.

Sosa, P.A. \& García-Reina, G. 1993. Genetic variability of Gelidium canariensis determined by isozymes electrophoresis. Journal of Phycology 29: 118-124.

Sosa, P. A., Jiménez, M. \& García Reina, G. 1993. Physiological comparison between gametophytes and tetrasporophytes of Gelidium canariensis (Gelidiaceae: Rhodophyta). Hydrobiologia 260/261: 445-449.

Sosa, P.A., Valero, M., Batista, F.J. \& González Pérez, M.A. 1998. Genetic structure of Gelidium species. A re-evaluation of results. Journal of Applied Phycology 10: 279-284.

Stroobant, M. 2004. Isoenzimatic, anatomical and reproductive analysis of Pterocladiella capillacea (S.G. Gmelin) Santelices \& Hommersand from Canary Islands (Spain) and Tuscany (Italy). MSc. Thesis. University of Pisa. 184 pp.

Vieira, V.M.N. \& Santos, R.O. 2010. Demographic mechanisms determining the dinamics of the relative abundance of phases in biphasic life cycles. Journal of Phycology 46: 1128-1137.

Zidane, H., Orbi, A., Sqalli, N., Zidane, F., Talbaoui, M., Hasnaoui, M. \& Fakhaoui, M., 2006. Survey of the cycle of reproduction of red algae $G e-$ lidium sesquipedale (Turner) Thuret (case of the maritime zone of El Jadida-Jarf lasfer of Morocco). Environmental Technology 27: 933-943.

Associate Editor: María Antonia Ribera Received: 26-VII-2012 Accepted: 27-XI-2012 